\title{
VETUS MELIUS EST \\ ZARZUTY NOWINKARSTWA I APOLOGIA TRADYCJI W SZESNASTOWIECZNYCH SPORACH MIĘDZY HUMANISTAMI A SCHOLASTYKAMI
}

Vetus melius est, „stare jest lepsze” — taką postawę zarzucał w 1519 roku Tomasz Morus swojemu przeciwnikowi, kartuzjanowi Johnowi Batmansonowi, przeciwstawiającemu się poprawianiu starego tłumaczenia Wulgaty ${ }^{1}$. Nie było to jednak prostym zdeprecjonowaniem starości jako takiej, bo przecież pamiętać musimy o samej naturze odrodzeniowego ruchu z napędzającym go hasłem ad fontes!', lecz odwołaniem do wieloznacznych słów Ewangelii św. Łukasza o młodym winie i starych bukłakach:

I nikt nie wlewa młodego wina do starych bukłaków, bo inaczej młode wino rozsadzi bukłaki i samo się wyleje, i jeszcze bukłaki zniszczeją. Lecz młode wino należy lać do nowych bukłaków. I nikt napiwszy się starego, nie chce od razu młodego; mówi bowiem: Stare jest lepsze. (Łk 5. 37-39)².

Tym zatem, co Morus chciał podkreślić, była względność stosowanych przez scholastyków kategorii, tak „starości”, jak i „młodości”, wynikające z ich nieświadomości historycznej pomieszanie przyczyny i skutku — podobne temu, z czym w swych apologiach borykali się pierwsi chrześcijanie. Z jeszcze większą wyrazistością wyśmiany jest ów zarzut rzekomego nowinkarstwa w satyrycznym dziełku Johannesa Jaegera z mniej więcej tego samego okresu, Teolodzy na naradzie, w którym opowiadający się za dominikańskim inkwizytorem i naczelnym przeciwnikiem Reuchlina, Jakubem Hoogstratenem, znany z polemik z Erazmem Edward Lee zarzeka się: „nigdy nie zaaprobuję tej nowej mody i tych nowych doktorów, Hieronima, Augustyna, Atanazego"3. Rzekoma nowość, w której obronie występowali renesansowi humaniści, była bowiem — jak sami wielokrotnie przypominali — przywróceniem czystości zbrukanej rzece trady-

\footnotetext{
* Dawid Nowakowski - (rocznik 1985) doktorant w Instytucie Filozofii Uniwersytetu Łódzkiego. Przedmiotem jego zainteresowania jest przede wszystkim myśl filozoficzno-religijna renesansu i reformacji, zwłaszcza zaś dzieło intelektualne Erazma z Rotterdamu. Publikował m.in. w „Twórczości”, „Folia Philosophica”, „Odrodzeniu i Reformacji w Polsce” oraz „Kronosie”.

${ }^{1}$ Cyt. za: E. Rummel, The Humanist-Scholastic Debate in the Renaissance and Reformation, Cambridge Mass. 1995, s. 98.

${ }^{2}$ Biblia, to jest Pismo Święte Starego i Nowego Testamentu, przekł. Brytyjskie i Zagraniczne Towarzystwo Biblijne, Warszawa 2010.

${ }^{3}$ J. Jaeger, Theologists in Council, [w:] Scheming Papists and Lutheran Fools. Five Reformation Satires, ed. E. Rummel, New York 2001, s. 57.
} 
$\mathrm{cji}^{4} \mathrm{i}$ odzyskaniem utraconego wzorca, zaciemnionego przez wymysły niedouczonych ludzi ${ }^{5}$. Tak więc, zarówno humaniści, jak i scholastycy, w swym własnym przekonaniu występowali jako obrońcy uświęconego długim trwaniem ładu, bliższego naturze status quo. Scholastycy humanistów zwalczali jako „miłośników innowacji”, tytułując Erazma mianem novitatis amator, które to określenie na konferencji zwołanej przez hiszpańskie zakony, by przebadać ortodoksyjność jego pism, pojawia się w werdykcie nie mniej, niż pięć razy ${ }^{6}$. Humaniści przedstawiani byli jako „nowi teologowie”, niedoświadczeni młodzieńcy pozbawieni odpowiednich kwalifikacji, by zajmować się poważnymi kwestiami ${ }^{8}$. Z drugiej strony scholastycy w krytyce humanistów również występują powszechnie jako theologi novi czy moderni i przedstawiani są pod postacią zdziecinniałych starców zajętych bez reszty pustą paplaniną, pozbawioną jakichkolwiek odniesień do spraw ważnych i istotnych. Ukonstytuowane w tej retorycznej polemice, czy też raczej w gwałtownym sporze, typy scholastyka i humanisty zaciążyły nad przebiegiem linii argumentacyjnych i znakomicie wpisały się w społeczne ramy pokoleniowego konfliktu między młodymi i starymi. Początek szesnastego wieku bowiem, podobnie jak późniejsze epoki Sturm und Drang, czy czasy Kriegskinder ${ }^{9}$, naznaczony był licznymi spięciami, jakie szczególnie silnie rysują się między generacjami w okresie kulturowych zerwań i przemian. To właśnie wtedy, w przededniu nowożytności, na świeżo założonych północno-europejskich uniwersytetach starli się ze sobą wykształceni w duchu paryskim scholastyczni dialektycy, z inspirowanymi powiewem klasycznej łaciny zwolennikami poezji.

Jakkolwiek — na co wskazuje James H. Overfield ${ }^{10}$ — nie sposób jednoznacznie wytyczyć linii podziału między scholastykami i humanistami w ich sporach, gdyż zdarzali się zarówno scholastycy broniący humanizmu (Pollich), jak i humaniści broniący scholastyki (Wimpfeling), daje się jednak dostrzec dwa socjologiczne typy: $\mathrm{z}$ jednej strony starzy mistrzowie, dobrze umocnieni na swych stanowiskach i opowiadający się

${ }^{4}$ Zob. Erazm z Rotterdamu, Metoda teologii, przekł. J. Domański, [w:] tenże, Trzy rozprawy, Warszawa 2000, s. 232, 463-464.

${ }^{5}$ Zob. Tamże, s. 196-197.

${ }^{6}$ E. Rummel, dz. cyt., s. 98.

${ }^{7}$ Listy ciemnych mężów, przekł. T. Brzostowski, Warszawa 1977 s. 226.

${ }^{8}$ Zob. E. Rummel, $d z$. cyt., s. 6 o znaczeniu tytułów w podejmowaniu dyskusji. Ale także u Erazma w listach (np. w liście z 1501 roku do Anny von Borselle: „,...] verum vt nunc tempora sunt, ita morem geras, quando nunc non dicam vulgo, sed etiam iis qui doctrinae principatum tenent, nemo doctus videri potest nisi Magister Noster appelletur, etiam vetante Christo theologorum Principe: cum antiquitus non ideo quis pro docto habebatur quod doctoris nomen esset mercatus, sed ii doctores dicebantur qui libris aeditis manifestum doctrinae specimen dedissent". Ep. 145, [w:] Opvs epistolarvm Des. Erasmi Roterodami, ed. P. S. Allen, t. 1, Oxford 1906, s. 345).

${ }^{9}$ Zob. Generations in Conflict. Youth Revolt and Generation Formation in Germany 1770-1968, ed. M. Roseman, Cambridge 2003, passim.

${ }^{10}$ J. H. Overfield, Humanism and Scholasticism in Late Medieval Germany, Princeton, New Jersey 1984, s. 207, 330. Wimpfeling jest autorem jedynego traktatu z początku XVI wieku w pełni poświęconego obronie scholastyki. 
w większości za podtrzymaniem obecnego stanu rzeczy, z drugiej zaś młodzi magistrzy poszukujący dla siebie i swoich zainteresowań miejsca w zastanym, bądź zmienionym, społecznym ładzie. Jak dowiadujemy się, na przykład ze zbioru dokumentów przedłożonych przez członków Uniwersytetu w Lipsku ich patronowi, księciu Jerzemu Saksońskiemu, starzy profesorowie, wskazując na znaczenie „senioralności” i utyskując na brak szacunku i wzgardę ze strony młodych magistri, odwoływali się jednocześnie do uniwersyteckiej tradycji i ustalonego porządku, łączącego władzę i przywileje z odpowiednim wiekiem ${ }^{11}$. Z podobnymi skargami i próbami ograniczenia wpływu młodych uczonych i humanistycznego ruchu spotykamy się również na innych niemieckich uniwersytetach, w Kolonii i w Heidelbergu ${ }^{12}$.

„Po co coś zmieniać, skoro jest dobre?” — tak zasadniczo brzmiała odpowiedź scholastyków na humanistyczne próby zmiany akademickiego curriculum $^{13}$. Przecież „vetus melius est”. Jak pisał Jakub Masson, ,źródłowy sens Pisma odnajdywany jest w swej najczystszej formie w wyjaśnieniach i komentarzach" scholastycznych doktorów i nie trzeba żadnych innych. Gabriel Biel zaś, którego znaczenie dla dziejów filozofii w obrębie via moderna, dzięki pracom Heiko Obermana jest coraz wyraźniej rozpoznawane, explicité odwoływał się do kategorii młodości i starości, wskazując na propedeutyczne znaczenie uniwersyteckiego kanonu — kierowanie nowicjuszy wprost do Biblii jest jak „wrzucanie noworodków do głębokiego i ogromnego morza”; Pismo jest „zbyt trudne, niemal bezużyteczne” dla początkujących i lepiej jest, by wpierw czytali Sentencje Piotra Lombarda i dyskutowali je scholastico more ${ }^{14}$. Na scholastyczny sprzeciw wobec humanistów — jak podaje Erika Rummel ${ }^{15}$ — składały się trzy podstawowe czynniki: opór wobec jakiejkolwiek zmiany, obawa przed zagrożeniem poganizmu i odrzucenie wyszukanego języka. Wszystkie zaś trzy ugruntowanie znajdywały w przekonaniu, że to scholastyka właśnie jest ostoją ortodoksji, że to ona broni odwiecznej prawdy przed niebezpiecznym nowatorstwem i herezją ${ }^{16}$.

Tymczasem wcale nie inaczej brzmiały zarzuty humanistów pod adresem scholastyków: „po co zmieniliście to, co było dobre?”. Ludwik Vives to właśnie w scholastycznej dialektyce widzi zarodki niebezpiecznego pragnienia oryginalności i waloryzowania zmiany dla samej zmiany:

Całą ich sztuką jest nie używać sztuki, lecz każdy z nich podróżuje swą własną drogą, dla własnej przyjemności, gdziekolwiek wiedzie, i myśli, że osiągnął wreszcie szczytny cel, gdy pod każdym względem różni się wielce od wszystkich innych i nie proponuje niczego, co byłoby głoszone przez kogoś wcześniej ${ }^{17}$.

\footnotetext{
${ }^{11}$ E. Rummel, dz. cyt., s. 63.

${ }^{12}$ J. H. Overfield, dz. cyt., s. 234-235; E. Rummel, dz. cyt., s. 66.

${ }^{13}$ Scholastycy godzili się na zmiany, a nawet sami się za nimi opowiadali, jedynie wówczas, gdy nie naruszały one istoty i zasadniczej formy średniowiecznego nauczania.

${ }^{14}$ Cyt. za: E. Rummel, dz. cyt., s. 7-8.

${ }^{15}$ Tamże, s. 16.

${ }^{16}$ Tamże, s. 126.

${ }^{17}$ „[Q] $]$ uorum est tota ars, nulla uti arte, sed sibi unumquenque pro libito viam facere, qua ingrediatur. Ac tum demum se rem assequutum praeclaram existimate, quum ab omnibus per omnia longe discrepat,
} 
Z wyobrażeniem dialektyków jako tych, którzy zrywają z obecną w klasycznej filozofii tradycyjną jednością mądrości i elokwencji, spotykamy się już u Leonarda Bruniego w jego Dialogach ${ }^{18}$, który pisze nawet, że gdyby Arystoteles powrócił do życia, nie rozpoznałby w występujących pod swym imieniem dzieł własnego autorstwa tak bardzo zostały zmienione! Humaniści widzieli w sobie legalnych spadkobierców dawnej tradycji, kogoś, kto przerzucając pomost ponad „ciemnymi wiekami” na nowo nawiązuje kontakt z pradawnymi pokoleniami, czerpiąc ożywcze soki z ich mądrościowej literatury. Petrarka rozmawia z Cyceronem, jak gdyby był mu współczesnym, jak gdyby — dzięki literaturze — można było zniwelować ponad tysiąc dzielących ich lat. To, co wydarzyło się w międzyczasie, staje się właśnie jakimś nieistotnym „międzyczasem”, media aevi, nie tyle wartościowym okresem kształtowania się tradycji, co raczej okresem zapomnienia. Humaniści, dzięki swej literackiej pamięci, choć historycznie młodsi, okazywali się być jednak od scholastyków duchowo starsi, posiadając większy autorytet. Zestawienie tej starczej głupoty scholastyków z młodzieńczą mądrością humanistów odnajdujemy w historyjce, jaką w swym liście z 1515 roku do Marcina Dorpa opowiada Tomasz Morus:

Sam spotkałem się z tym przekonaniem [że nie ma prawdy poza summules — dop. D.N.] nie tak dawno temu w sklepie księgarza. Był on starym człowiekiem, z jedną nogą — jak się to mówi — w grobie, i drugą z pewnością nieodległą od niego; księgarz ów został przed ponad trzydziestu laty wyróżniony, jak to nazywają, honorowym doktoratem. Zdarzyło się, iż powiedziałem do niego: „Św. Augustyn uważał kiedyś, że wszystkie duchy są cielesnymi substancjami”. Od razu ściągną swe brwi i zmierzył mą zuchwałość niezadowolonym spojrzeniem. Kontynuowałem: „Nie mówię, ojcze, że bronię tego stanowiska, ani Augustyna w tej kwestii. Był on człowiekiem, mógł więc się mylić. Wierzę, że był wielkim geniuszem, lecz nikt nie jest doskonały”. Wówczas człowiek ten poważnie zaczął się zapalać, zwłaszcza dlatego, że uczyniłem tak niegodny zarzut przeciwko takiemu Ojcu. „Czy myślisz, że ja — rzecze — nie czytałem Augustyna? Zaiste czytałem,” mówi, „i to zanim się urodziłes”. I z pewnością zmieszałby mnie tymi ostrymi słowami, gdyby odparcie nie leżało w zasięgu ręki. Bowiem, gdy byliśmy w księgarni, podniosłem niewielki tom De divinatione daemonum Augustyna, przewróciłem kartę i pokazałem mu. Wpierw przeczytał on ów fragment raz i drugi i dopiero za trzecim czytaniem (i to z moją pomoca) zaczął go rozumieć, pełen zdumienia. „Cóż” — powiedział — „jestem bardzo zdumiony tym, co Augustyn mówi w tej księdze, ponieważ z pewnością nie mówi tego w Mistrzu sentencji, która jest bardziej magisterialną księgą, niż ta”. Ludzie z takiego zacieru, którzy nigdy nie czytali żadnych antycznych pisarzy, ani niczego z Pisma za wyjątkiem tego, co jest w Sentencjach i ich komentarzach, wydają się mi dokładnie tacy, jak człowiek, który pomija wszystkich piszących po łacinie autorów, poszukuje gramatycznych konstrukcji w zasadach Aleksandra i próbuje uczyć się reszty łacińskiego języka z Cornucopii Perottusa i od Calepino, ponieważ jest przekonany, że u nich można znaleźć wszystkie łacińskie słowa ${ }^{19}$.

nihilque sic tradit, ut ab aliquo alio est antea traditum". L. J. Vives, Against the Pseudodialecticos, s. 74. Zob. też: Erazm z Rotterdamu, Apologia contra Latomi dialogum, [w:] tenże, Opera omnia, Lvgdvni-Batavorvm 1706 (LB), t. 9, kol. 86b.

${ }^{18}$ E. Rummel, dz. cyt., s. 44.

19 "In cuius animi quendam etiam ipse iam olim quadam bibliopolae taberna incidi; erat enim senex, qui alterum (vt aiunt) pedem habebat in sepulchro, et certe non multo post vtrumque, iam doctoratus (vt vocant) honore plusquam annos triginta fuerat insignitus. Dico forte apud eum, beatum Augustinum aliquando putasse, demones omneis substantias esse corporeas. Ibi ille statim supercilium contrahere, et temeritatem meam rugosa fronte compescere. Tum et, 'Non dico,' inquam, 'hoc ipse, Pater, nec 
Prowadzona na wielu frontach humanistyczna krytyka niestrudzenie obnażała ową doktrynalną jałowość scholastyki. Posiłkując się wiedzą historyczną, obyciem w literaturze i umiejętnościami retorycznymi odrzucała jedno za drugim kolejne jej roszczenia: na płaszczyźnie filozoficznej, pokazując ograniczoność dialektyki wtedy, gdy zestawi się ją z sylogistyką i retoryką, na płaszczyźnie historycznej, wykazując krótkość trwania i brak ciągłości scholastyki z tradycją zachodnią (krytyka Awerroesa) ${ }^{20}$, na płaszczyźnie filologicznej, ujawniając zatracenie naturalności języka, gdy wraz z wprowadzeniem gramatyki spekulatywnej zniesiono jego idiomatyczną funkcję ${ }^{21}$, na płaszczyźnie etycznej, wskazując na oderwanie scholastyki od życia i wreszcie, na płaszczý́nie teologicznej, oskarżając ją o zapoznanie praktycznego aspektu teologii i egzystencjalnego znaczenia aktu wiary ${ }^{22}$. Przez wzgląd na swą niepamięć i niewiedzę, ta chełpiąca się swą starożytnością scholastyka, okazywała się być tylko zdziecinniałą staruszką - miana tego używa Vives w stosunku do Uniwersytetu Paryskiego ${ }^{23}$ która we własnej głupocie odnajduje najsilniejsze wsparcie dla swej dumy. Scholastycy, powie Erazm w swym młodzieńczym dziele Antibarbari, nie byliby tak pyszni, gdyby nie byli tak głupi:

Gardzą oni elokwencją Cycerona, będąc sami niemymi jak ryby; gardzą oni bystrością Chryzypa a sami są tak tępi jak największe tłuki. Gardzą oni poezją, będąc niewtajemniczonymi i, jak mówi Platon, obcymi dla Muz.

[...] Spostrzegam — mówi dalej Batt — że Kwintylian widział to jasno: „im mniej jest wart umysł jakiejś osoby, tym bardziej próbuje ona się wywyższyć i zwiększyć swoją ważność”. Widzimy wielu ludzi, którzy zdają się sobie najwyższymi uczonymi, nim posiądą jakąkolwiek ideę o tym, co znają lub czego nie znają. Od kiedy przekonali samych siebie, a przez swą głupotę zdobyli pewną reputację erudycji wśród

\footnotetext{
Augustinum in ea re defendo. Homo erat, errare potuit. Credo ei quantum cui plurima, sed nemini vni omnia.' Iam vero coepit homo excandescere, vel ob id precipue, quod tanto Patri calumniam tantam intenderem. 'Nam putas me,' inquit, 'non legisse Augustinum? Imo,' inquit, 'priusquam tu nascereris.' Me iam suis seuis dictis protelasset, nisi commode fuisset paratus eenchus. Nam vt erat in taberna, sumo in manus libellum Augustini de Diuinatione Demonum, verto ad locum, atque ostendo; vbi locum semel atque iterum legit, ac tercia demum lectione, me adiuuante, coepisset intelligere, tandem admirabundus. 'Certe,' inquit, 'ego valde miror de hoc quod Augustinus dicit sic in isto libro, quia certe non dicit sic in Magistro Sententiarum, qui est liber magis magistralis quam iste.' Qui sunt ex hac farragine, qui neque Veterum quenquam, neque Scirpturarum quicquam legunt, nisi in Sententiis, et earum commentariis, hi perinde mihi videntur facere, ac si quis authoribus omnibus qui Latine scripserunt omissis, constructionum praeceptis ab Alexandro petitis, reliquum Latinae lingaue ex Perotti Cornucopia, et Calepino conetur ediscere, quod persusum habeat, in his omnia Latinae linguae vocabula sese reperturum, et profecto reperiet plurima, eademque electissima”. Cyt. za: L. J. Vives, dz. cyt., s. 184-186. Wszystkie przekłady, o ile nie zaznaczono inaczej, są dziełem autora artykułu.

${ }^{20}$ Humaniści często podawali dokładny wiek i historyczne początki scholastyki jako takiej. Np. Vives (dz. cyt., s. 95) mówi o pięćsetletnim okresie trwania scholastyki, a Erazm zazwyczaj jej początki łączy z Sentencjami Piotra Lombarda (I. Bejczy, Erasmus and the Middle Ages. The Historical Consciousness of a Christian Humanist, Leiden-Boston-Köln 2001, s. 63).

${ }^{21}$ Zob. I. Bejczy, dz. cyt., s. 66-67.

${ }^{22}$ Zob. Tamże, s. 75, 105.

${ }^{23}$ L. J. Vives, dz. cyt., s. 103.
} 
pospolitego tłumu, jest niemożliwe, by nie mieli ani odrobiny uznania dla siebie i nie gardzili innymi. Śmiało nauczają oni tego, czego nie wiedzą; piszą, mówią, wyjaśniają; nie ma niczego, co zostawiliby nie poruszonym, niczego nie przepuszczają; polegając na aplauzie swych zwolenników, szydzą z osądu uczonych i ich niewielkiej ilości; są oni zgubą rodzaju ludzkiego, a ich umysłowy światopogląd stoi w zgodzie $\mathrm{z}$ ich głupotą ${ }^{24}$.

Głupota bowiem, zauważa - w Moriae encomium Erazm — choć jako taka charakteryzuje przede wszystkim młodość, towarzyszyć może również i starości, jeśli ta jest zdziecinniała ${ }^{25}$. Zdziecinnieniem zaś słusznie będzie nazwać stan polegający na zajmowaniu się zajęciami właściwymi dzieciom, będąc już w dorosłym wieku. Skoro zaś dialektyka, jako należąca do trivium, powinna być uprawiana raczej u początku nauki i to w młodym wieku, po co starcom ćwiczyć w niej umysł, jeśli i tak nigdy nie zaczną go poważnie używać i do końca życia trwać przy tych dziecięcych igraszkach ${ }^{26} \mathrm{Nie}$ jest bowiem dialektyka — jak podkreślił Vives — „sztuką, która powinna być uczona dla samej siebie, lecz by wesprzeć inne sztuki”.

Człowiek, który — czytamy u Vivesa — spędza długi czas na dialektyce i nie stosuje jej do innych gałęzi nauki jest jak ów, który kupiwszy sito, by przesiać mąkę i zrobić chleb, spędza długie godziny na składaniu i układaniu narzędzi. [...] Tylko głupiec czyni długie i pełne niepokoju usiłowania złożenia narzędzia, zamiast niezwłocznie zabrać się do pracy, do której to narzędzie jest przeznaczone ${ }^{27}$.

Już Petrarka nazywał tych „nowoczesnych” teologów senes pueri, biorąc swe wyrażenie, jak wykazał Eugenio Garin z komentarza Chalcydiusza do Timajosa: „Tych Arystoteles chłopięcymi starcami nazywał, których umysł niewiele różnił się od umysłu chłopców" ${ }^{28}$. To, jak komiczny widok przedstawiają ci nigdy niedojrzewający starcy, uzmysłowił ku przestrodze Erazm w swej Metodzie teologii:

A tymczasem — cóż to za widowisko, gdy taki osiemdziesięcioletni teolog nic nie robi innego, tylko albo innych w szkole naucza uprawiać dialektyczne i filozoficzne zapasy, albo sam je uprawia. Tutaj gada bez

\footnotetext{
${ }^{24}$ „Ciceronianam contemnunt eloquentiam homines mutis piscibus mutiores, Chrisippi contemnunt acument, cum sint ipsi quouis pistillo retusiores. Poesim contemnunt prophani et (vt inquit Plato) longe a Musis alieni. [...] Quod idem Quintilianum probe vidisse, intellogi. Quo quisque, inquit, ingenio minus valet, eo magis attollere se ac dilatare conatur. Videmus enim permultos, priusquam quid sciant aut nesciant, satis cognitum habeant, iam sibi consummate doctis videri. Hi postquam et sibi persuaserunt et dementia sua nonnullam apud vulgus eruditionis opinionem sunt aucupati, et sibi non parum tribuant et alios fastidiant necesse est. Docent audacter quae nesciunt, scribunt, orant, interpretantur, nihil non tentant, nihil non audent, suis applausoribus freti, eruditiorum tum iudicia, tum paucitatem contemnunt. Pestilens hominum genus et sua mente suaque stoliditate dignum". Erazm z Rotterdamu, Antibarbari, ed. K. Kumaniecki, [w:] Opera omnia Desiderii Erasmi Roterodami, (ASD) I-1, Amsterdam 1969, s. 76-77, 87.

${ }^{25}$ Erazm z Rotterdamu, Pochwała gtupoty, przekł. E. Jędrkiewicz, Warszawa 2001, s. 24-25.

${ }^{26}$ Zob. L. J. Vives, $d z$. cyt., s. 81.

${ }^{27}$ L. J. Vives, $d z$. cyt., s. 89.

${ }^{28}$ Chal. Com., CCIX; Petrarka, Le Familiari, I.7 (cyt. za: R. Guerlac, Introduction, 1979, [w:] L. J. Vives, dz. cyt., s. 14).
} 
końca - do głoszenia ewangelii Chrystusowej brak mu języka. Do końca życia nic innego nie czyni, tylko oddaje się dysputom, żeby już nie powiedzieć, że opowiada brednie ${ }^{29}$.

Owo zestawienie spodziewanej powagi u dostojnego starca z jego oddawaniem się dziecięcym igraszkom, czy też — jak powie Erazm w liście dedykacyjnym tłumaczenia Uczty Lukiana dla Johanna Hutticha (?) — dziecięcej „paplaninie”, stanowi powszechny chwyt w kierowanym przeciw scholastyce ostrzu satyry ${ }^{30}$. Wtedy jednak, gdy na postawę scholastyków spojrzy się z perspektywy znacznie szerszej, z perspektywy naczelnego celu doskonalenia się człowieka, który to cel stanowił i nadal stanowi fundament wszelkiego prawdziwego humanizmu, niewinne z pozoru dialektyczne igraszki okazują się być niebezpieczną pułapką odbierającą człowiekowi rzecz niezwykle cenną, choć rzadko w porę docenianą - mianowicie, odbierają czas. Poczucie zmarnowanego czasu, rozminięcia się z pierwotnym celem poszukiwań — nieobce chyba również i naszym czasom — było doświadczeniem, z którym borykało się wielu średniowiecznych akademików, choć — rzecz jasna — nie wszyscy chcieli się do tego, jak nauczyciele Vivesa, Dullaert i Gaspar Lex, przyznać. Vives wspomina, że często słyszał ich uskarżających się gorzko, że „spędzili tak wiele lat w tak pustej i bezużytecznej pogoni”"31. Niech ci - powie w innym miejscu — którzy pragną poznać te rzeczy, uczą się ich, „ale w kilka krótkich miesięcy, by zrozumieli, jak są one bezsensowne”. Cytuje też „biednego, głupiego Teofrasta”, uskarżającego się, że życie jest zbyt krótkie, by nabyć prawdy w dyscyplinach prowadzących „do mądrości, dobra i szczęśliwego życia, tak że umieramy, gdy tylko staniemy się odrobinę mądrzy!” Tymczasem scholastycy marnują całe swe życie na „brednie odpowiednie dla starych kobiet”"32.

Próżność dialektycznych kwestii, którymi zajmowanie się odbiera cenne lata młodości i życia, nie przydając jednocześnie oczekiwanej od starości mądrości, w sposób mistrzowski wykpiwa Rabelais, gdy opowiada, jak to Tęgospust, zobaczywszy niewątpliwe oznaki rozumu u syna swego Gargantui, postanawia oddać go scholastykom na naukę:

Jakoż w istocie przydano mu wielkiego doktora teologii, nazwiskiem mistrz Tubal Holofernus, który nauczył go tak dobrze abecadła, iż recytował je z pamięci od końca. Co zajęło mu pięć lat i trzy miesiące. Potem czytywał mu Donata, Faceta, Theodoleta i Alanus in Parabolis, na czym zeszło trzynaście lat, sześć miesięcy i dwa tygodnie. [...]

Potem mu czytywał de Modis significandi, z komentarzem mistrzów Pyskatego, Nicpotem, mistrza Jana Ciołka, Stękały, Kujona i wielu innych; na czym zeszło więcej niż osiemnaście lat i jedenaście miesięcy. [...]

\footnotetext{
${ }^{29}$ Erazm, Metoda teologii, s. 206.

${ }^{30}$ Ep. 550, [w:] Opvs epistolarvm Des. Erasmi Roterodami, ed. P. S. Allen, Oxford 1910, s. 503. Zob. też List Tomasza More'a do Marcina Dorpa z 1515 roku, [w:] L. J. Vives, dz. cyt., s. 190.

${ }^{31}$ L. J. Vives, $d z$. cyt., s. 99.

32 Tamże, s. 87. O scholastykach jako o marnujących swe życie na rzeczach bezwartościowych pisał również Jakub Locher w mowie O studiach humanistycznych w pochwale poezji (1496; za: E. Rummel, dz. cyt., s. 78).
} 
Potem mu czytał Computum, na czym strawił Gargantua szesnaście lat i dwa miesiące; w tym to czasie jego preceptor umarł [...].

Po nim miał jeszcze drugiego starego stękałę, zwanego mistrz Pała Zakuta, który mu czytywał [liczne dzieła] [...]; z których to dzieł stał się tak mądry, jak był w bebechach swojej matki. [...].

Owóż ojciec jego spostrzegł, iż mimo że chłopiec kształci się bardzo pilnie i obraca cały swój czas na naukę, wszelako nic mu to nie płuży, a co gorsza, staje się z tego pomylony, przygłupiasty, zatumaniony i jołopowaty. Za czym gdy się wyżalał przed don Filipem Marejskim, wicekrólem Papeligossy, rzekł mu tamten, iż lepiej by było chłopcu niczego się nie uczyć niż uczyć się z takich książek pod takimi preceptorami. Bowiem ich cała nauka to jeno błazeństwo, a mądrość ich to wierutne bzdury służące do zbękarcenia dobrego i szlachetnego umysłu i zatruwające cały kwiat młodzieży ${ }^{33}$.

Nieprzydatność scholastyki najlepiej spostrzec, obserwując zachowanie dawnych mistrzów uniwersyteckich, którzy gdy tylko opuszczą szkołę, natychmiast stają się głupi i milczący, a wszelka ich wiedza znika niczym dym. Według Vivesa:

Cały swój scholastycyzm pozostawiają wraz ze szkołami i nie mają już o czym gadać. Nieoczekiwanie ci, którzy niegdyś przewyższali w paplaniu kobiety i sroki, bardziej donośni nawet niż Stentor, grecki herold w Troi, teraz biją w milkliwości same ryby $[\ldots]^{34}$.

Ujawniwszy w swej krytyce prawdziwą naturę scholastyki, będącej pustą grą, w której nie wygrywa się nic, a przegrywa życie, humanizm kieruje odezwę, ale nie do młodzieży — jak zapewne miałoby to miejsce w dzisiejszych, postromantycznych, wojnach pokoleniowych — gdyż ta, zgodnie z klasycznymi przekonaniami wciąż jeszcze nie potrafi używać samodzielnie rozumu, lecz do samych tych przegranych starców, do tych, którzy doszedłszy do kresu scholastycznej drogi, choć sami nie moga już zawrócić, wciąż jeszcze zdolni są powstrzymać innych. Nieuczynienie tego, staje się w perspektywie moralnej nie tylko błędem, ale również i winą ${ }^{35}$. Kończy swój traktat Vives:

Nie zabiegam o względy młodzieńców, którzy nie mają zrozumienia, osądu, ni władzy rozróżniania; lecz pragnę znaleźć posłuch u starszych ludzi, kiedy wiek przydał już im nieco lepszy osąd ${ }^{36}$.

Słowa te mają zupełnie inny wydźwięk w drugiej połowie XVI wieku, gdy myśliciele, tacy jak Francis Bacon, ze swoim dowartościowaniem roli doświadczenia i eksperymentu, złączą je z historiozoficzną ideą intelektualnego postępu. Tak samo

\footnotetext{
${ }^{33}$ F. Rabelais, Gargantua i Pantagruel, przekł., E. Boye, t. 1, Warszawa 1955, s. 45-47.

34 „Scholastica illa omnia simul cum scholis relicta sunt; alia nulla habent quae loguantur; necesse est, ut qui prius a nullis picis, a nullis mulierculis garrulitate vincebantur, ipso etiam Stentore Graecorum apud Trojam praecone vocaliores, tunc silentio pisces quoque vincant, et ex nostratibus ranis fiant acanthiae". L. J. Vives, dz. cyt., s. 92-93.

${ }^{35}$ Tamże, s. 100-102.

${ }^{36},[\mathrm{~N}]$ on placeo juvenibus, quibus nullum est consilium, nullum judicium, nulla mens, at senibus placebo, cumu illis aetas melioris judicii nonnihil attulerit [...]”. Tamże, s. 105.
} 
bowiem jak u człowieka młodość łączy się z pewną nieświadomością i niewiedzą, tak samo młodość historii łączy się z niedojrzałością intelektualną, omylnością i brakiem właściwego osądu. Antiquitas seculi, iuventus mundi - powie Bacon. Starożytność klasyczna, jakkolwiek jej obecność na drodze rozwoju ludzkości była nieodzowna, nie miała na tyle szerokiej perspektywy i rozeznania, by móc we właściwy sposób zrozumieć znaczenie posiadanej przez siebie wiedzy. Epoka nowożytna, dzięki z jednej strony odzyskanej za sprawą humanistów pamięci, i z drugiej — dzięki swemu dojrzałemu wiekowi, wyrasta ponad poziom tego, co osiagnęli Rzymianie i Grecy i przekraczając granice znanego świata, wypływa na nieznane morze poznania. Odtąd „nowość”, „świeżośc”, a nawet kartezjańska „oryginalność” przestały być oznakami błędu, zwiastując jutrzenkę nowej ery, upragnionego Państwa Bożego osiemnastowiecznych filozofów. To, czy starość spełniła marzenia o dojrzałości, jest pytaniem, które stoi już poza kręgiem moich rozważań i zostawiam je tutaj otwartym.

Dawid Nowakowski

23 maja 2014 roku

Dawid Nowakowski

\title{
VETUS MELIUS EST \\ Allegations of Novelty and Apology of Tradition in the Sixteenth-Century Quarrels BETWEen Humanists and SCHOlastics
}

\author{
Summary
}

The paper presents the $16^{\text {th }}$-century dispute between scholastics and humanists over the proper shape of intellectual tradition. Each side, using the motto "vetus melius est", accused the other of inexcusable innovation. The first group reveals strong unwillingness to any change and fed conviction that only maintaining of status quo will secure the Christianity. The second pointed to the poor memory of scholastics, who forgot the real ancient culture, and proclaimed that the change is not an innovation, but a restoration. In the end of the paper the author suggests an existence of possible relation between the humanist attitude toward tradition and the emergence of modern idea of progress.

Słowa kluczowe: spory humanistów ze scholastykami, antykwaryczność i idea postępu, scholastyka i humanizm, konflikt pokoleń

Keywords: quarrels between humanists and scholastics, antiquarism and idea of progress, Scholasticism and Humanism, generation conflicts 